Editorial

\title{
The Lived Experiences of Migration: An Introduction
}

\author{
Neli Demireva ${ }^{1, *}$ and Fabio Quassoli ${ }^{2}$ \\ ${ }^{1}$ Department of Sociology, Essex University, CO4 3SQ, Colchester, UK; E-Mail: nvdem@essex.ac.uk \\ 2 Department of Sociology and Social Research, University of Milano-Bicocca, 20126 Milan, Italy; \\ E-Mail: fabio.quassoli@unimib.it \\ * Corresponding author
}

Submitted: 18 October 2019 | Published: 7 November 2019

\begin{abstract}
This editorial presents a general overview of the thematic issue "The Lived Experiences of Migration: Individual Strategies, Institutional Settings and Destination Effects in the European Mobility Process," based on the rich qualitative data produced in the Growth, Equal Opportunities, Migration and Markets (GEMM) project. The qualitative component of the project focused on the 'lived' experiences of migration. The main contribution of the articles in this issue is to demonstrate the multiplicity of actors and structures involved in the migration process, and to recognize the important role that space plays in the life-trajectories of people on the move. Perceiving the migration process as a learning experience allows for a deeper look into the complex renegotiation of cultural and political boundaries that migrants experience in the destination.
\end{abstract}

\section{Keywords}

Central-Eastern Europe; cosmopolitanism; EU mobility; identity change; language; migrant motivations; migrant recruitment practices; social capital; social imagination; social networks; prospective migrants; Southern Europe

\section{Issue}

This editorial is part of the issue "The Lived Experiences of Migration: Individual Strategies, Institutional Settings and Destination Effects in the European Mobility Process" edited by Neli Demireva (University of Essex, UK) and Fabio Quassoli (University of Milano-Bicocca, Italy).

(C) 2019 by the authors; licensee Cogitatio (Lisbon, Portugal). This article is licensed under a Creative Commons Attribution 4.0 International License (CC BY).

\section{Introduction and Overview of the Qualitative Part of the GEMM Project}

This thematic issue is based on the rich qualitative data produced in the GEMM (Growth, Equal Opportunities, Migration and Markets) project. The focus of GEMM has been the understanding of the individual and structural barriers that might prevent migrants from realizing their human capital potential. The qualitative component of the GEMM project focused on the 'lived' experiences of migration. It builds upon the understanding that mobility is a complex and dynamic process starting with the decisions that are made before and along the journey, and proceeding with examination of the challenges to migrants' early adaptation, work and social integration, and the changes in their feelings of belonging and citizenship status.
The research examined the impact of cross-cutting factors such as gender, nationality, skill level and occupational sector. Using qualitative methodology, primarily in-depth interviews, the team collected a rich set of data that provides invaluable insights into the motivations of migrants and the mobility channels they use. Furthermore, the interviews reflect well upon the complex interplay between push and pull factors that migrants experience and on their relationship to the sending and receiving contexts. Thus, the interviews cover a wide range of themes including: the climate of reception and levels of discrimination by employers; the transferability of migrants' own human capital; and the success with which they view their own journeys. 


\subsection{Main Research Questions of the GEMM Study and Overall Approach}

Several research questions shaped the analysis in the GEMM study and are well reflected within this thematic issue. In particular, the submissions in this thematic issue have focused on the varying motivations for mobility on the part of different groups of people and on the factors that explain their choice of destination country; on the myriad of ways in which those who are about to leave prepare for the radical change in their life circumstances that migration represents; and finally on the formal and informal channels for mobility that have been used in the migration process.

The contributions in this thematic issue draw on the understanding of migration as a complex and dynamic process of mobility which starts with the initial aspirations and hopes of the migrant, and is never quite over even when the desired destination has been reached successfully. We considered migration as influenced by a wide range of individual, institutional and contextual factors. While many studies based on large-scale survey data have examined the profiles of mobile Europeans and the influence of gender, education, family situation on migration (Arslan, Effenberger, Luecke, \& Omar Mahmoud, 2009; Cangiano, 2015; Cummings, Pacitto, Lauro, \& Foresti, 2015; Kogan, 2006; Triandafyllidou \& Gropas, 2014), this thematic issue considers the multilayered nature of the individual decision-making, and captures the human story at the centre of the migration process through the analysis of the cultural values, meaning making and identity development of the mobile individuals. Thus, our approach differs from those of neoclassical economic studies but also from research in the ethnography of migrant communities, which usually focuses on networks and mechanisms for cultural transmission but ignore the impact of the economic and political context of the increasingly interrelated European societies. While being aware of the broader debates in the migration literature (Czaika \& de Haas, 2014; King, 2012; O'Reilly \& Benson, 2009) the main contribution of this thematic issue lies in portraying the variety of life experiences of people on the move, and in exposing the complex interplay between their individual agency and the structural opportunities available to them.

\subsection{Fieldwork and Sampling Design of the GEMM Study}

With the view to capture the dynamics of the process of mobility, the design of the sample focused on two types of migrants: 'potential,' that is, people who plan to migrate in the near future (not longer than one year), and 'actual,' that is, people who are already living in a foreign country (for at least two years). Moreover, we selected three groups of countries for conducting the fieldwork: countries traditionally receiving migrants such as Germany and the UK; countries traditionally sending migrants such as Bulgaria and Romania; and countries which at present are both receiving and sending migrants such as Italy and Spain. The selection allows us to examine a range of regional and national contexts in which migrants are embedded and to give due diligence to the pan-European policy debates and regulations that might shape the migration process.

The interviews were designed to examine the motivation for migration and the process of decision making and preparation, as well as to cover the actual migration steps and finally to track down the process of adaptation, work and life in the new country, the changes in migrant's identity and expectations for the future. We also took into consideration the public debates and policy regulations in the sending and receiving countries, the economic, political, cultural trends that might influence the decision to migrate and the choice of the destination country, which might largely be conceptualized as institutional and contextual factors of migration. The fieldwork of six country teams from Bulgaria, Romania, Italy, Spain, Germany and the UK resulted in 236 in-depth interviews in total. Of these, 154 were conducted with 'actual migrants', that is, people who had migrated from four sending countries Bulgaria, Romania, Italy, and Spain and who lived in four receiving EU countries-UK, Germany, Spain and Italy. In the group of actual migrants there were 16 interviews conducted with non-EU migrants from China and the USA in Germany and the UK in order for us to be able to examine differences between EU and non-EU highly-skilled migrants. Additionally, 42 'prospective' migrants were interviewed at home in Bulgaria, Romania, Italy, and Spain about their plans to migrate in less than 12 months to an EU country. Furthermore, the collection contains 40 interviews with experts from public and private recruitment agencies. More information on the data can be seen at the online page of the UK Data Service (n.d.) where the data has been deposited.

\section{Common Themes Emerging in the Thematic issue}

This section reflects on several very important themes that this thematic issue brings to the fore.

\subsection{Sources of Support and Local Contexts}

Fischer-Souan (2019), Demireva (2019) and Popivanov and Kovacheva (2019) illustrate that migrants rely heavily on informal channels of support for the first and most uncertain steps of their adaptation in the host countries. Our observations in this sense are in line with a dominant trend in the literature on the informal pathways chosen by specifically low-qualified migrants (Giulietti, Schluter, \& Wahba, 2013; Maeva, 2017). All three studies stress the importance of informal social connections which can play significant role in job search and house hunting. Crucially, co-nationals are important brokers of information and can provide interpretation and translation services to the newly arrived migrants. Informal sources of support are also prevalent among Italian mi- 
grants when administrative issues are concerned (such as the opening of a bank account or registration with professional bodies).

As the article by Coletto and Fullin (2019) points out, social media is an ubiquitous source of information, and many interviewees claimed that Facebook groups or blogs have been a major factor facilitating their adaptation. Employers also played a role, and Spanish interviewees in particular and medical professionals in general suggested that they have been assisted in their initial steps by respective employers in Germany or the UK. Such practices were rarer in other sectors although there was evidence of existing provisions in engineering, finance and digital commerce.

\subsection{Recruitment Agencies and Prospective Migrants}

Both the contributions of Kovacheva, Popivanov, and Burcea (2019) and of Demireva (2019) highlight the important role that recruitment agencies play in facilitating the mobility process. Dominant in the discourse of private recruiters was the personal link they maintained with jobseekers and employers, as well as the psychological support they felt they provided to emigrants. Moreover, there were also important first 'sieve' of candidates that guaranteed to host country employers the presence of workers who not only had the right skills but also exhibited high levels of commitment and work ethic. Migrants were sometimes ambivalent however of the positive role of recruitment agencies (see Demireva, 2019). Some felt that these institutions guarded the rights of employers rather than those of the migrants; and many preferred to directly approach employers once they became more established.

\subsection{The Cultural Dimension of Intra-EU Mobility: Identity and Belonging beyond National Borders}

In the last two decades, people on the move have been categorized in various way, from migrants and economic migrants, mobile people and guest workers, to expatriate, transnational people, lifestyle migrants, mobile gentrifiers, and more (Barbulescu, 2017; Bauman, 2000; Benson \& O'Reilly, 2016; Conradson \& Latham, 2005; Engbersen, 2018; Favell, 2008; Florida, 2002; Glick Schiller, 2003). These categories are central in the process of identity reconfiguration that always characterized life-trajectories of people on the move. As it is the case for other types of labels, such as those that concern gender or ethnicity, they are used to implicitly generate a distinction between those who have the power to impose such labels and those who have to deal with them (Gallissot, Rivera, \& Kilani, 1997). Several contributions in this thematic issue, in particular Quassoli and Dimitriadis (2019) comment on the malleability of labels and on the political aspects of mobility noted in other studies as well (Conradson \& Latham, 2005; Parutis, 2011). Fischer-Souan (2019), comparing mobility trajectories of
Southern European and Eastern European interviewees, discussed an often drawn distinction between economic and lifestyle migrants. Whereas the former are often seen as defined through their economic needs and career trajectories, the focus in the latter is the aspiration for better lifestyles, new and exciting cultural experiences (see also O'Reilly \& Benson, 2009). Our evidence is however much more nuanced, and the lifestyle migrants in our sample also aspire to escape the dire job prospects of the sending country and the economic hardship they face at home, while economic migrants embrace the move away and the search for self-fulfilment.

To further complicate the picture that the submissions in this thematic issue are painting, we need to consider the local context in which the immigrants have become embedded as it has an impact upon their sense of belonging and perceived class position. As we can see in Quassoli and Dimitriadis (2019), there is a very specific cosmopolitan identity to which migrants living in London or Berlin subscribe, and of which exceptionalism in relation to the UK and Germany they are very aware.

Perceiving and narrating oneself in a certain fashion involves the activation of social imagery. The ways in which a given group of people imagines and narrates the social reality of their situation (Castoriadis, 1997; O'Reilly, 2014) can create shared meanings and moral values, and generates a sense of both common belonging and fate (Benson, 2012). The contribution of Coletto and Fullin (2019) convincingly highlights that social imagination plays a relevant role in the migration decision, in the choice of city/country of destination and in the way mobility is represented and narrated. Thus, the authors stress that it is not the careful consideration of the costs and benefits of the mobility process (Benson, 2012; Salazar, 2011) that propels migrants into their journeys but rather the image of London and Berlin as lively, dynamic and attractive global cities, together with the perception of intra-EU mobility as smooth and free.

Identity reconfiguration and the emergence of a new a sense of belonging is another crucial aspect of the mobility process. Again, Quassoli and Dimitriadis (2019) explore in a comparative manner the identity formation among Italian and Spanish people living in London and Berlin. The authors propose three types of identity with which migrants end up: the development of a stronger cultural attachment to the country of origin; the internalization of the national culture of the host society, together with the development of a more critical vision of the society of origin than the one previously held; and a downplaying of the national cultural model and the development of cosmopolitan/European identity. The latter identity can indeed be seen as the founding pillar of supranational political communities (Goulahsen, 2017). Thus, identity is hardly static, and research should allow for the formation of multiplicity of identities that can be further moulded by positive as well as negative interactions with the receiving and sending societies (Quassoli \& Dimitriadis, 2019). 


\subsection{Ethnic Niches and Language}

Preparation before departure for many of the migrants in the GEMM study involved learning the language of the destination country. Both politicians and academics frequently focus on the linguistic competence of the migrant as the main factor facilitating their integration both in terms of labour market and cultural adaptation (see Cameron, 2011; Koopmans, 2015). In this thematic issue, Demireva (2019), Coletto and Fullin (2019) and Fischer-Souan (2019) speak of the important role of language for integration moderated by the skill levels of the migrants as well as the specificities in certain industries. Healthcare professionals reported the highest level of pre-migration host country language proficiency or language school enrolment immediately after arrival, because they were directly blocked from becoming registered practitioners without sufficient local linguistic capacity. There was clear evidence however of the existence of powerful transnational elites (Ryan \& Mulholland, 2014) in finance for example who did not necessarily embed themselves linguistically in their new environment and instead fully embraced the cosmopolitan aspect of their migration journey.

Ethnic niches were both feared and greatly appreciated. On the one hand, they could contribute to linguistic isolation from the mainstream (see Demireva, 2019), however, they also guaranteed some sense of comfort and protection especially for newly arriving immigrants (Demireva, 2019; Popivanov \& Kovacheva, 2019). Thus, the evidence of the role of ethnic niches remains ambivalent. It is worth noting that for many migrants the experience of ethnic niches was transitory-they may reside in one, in the beginning, but settlement usually meant residential and job mobility away from the ethnic economy. This was the case however for the highly and mediumskilled migrants rather than the low-qualified ones.

\section{Conclusion}

This thematic issue highlights that any analytical categories that we use to study human mobility-class, gender, ethnicity, generation, or lifestyle-must be grounded in some local context. Moreover, researchers should expect that these categories can operate in very peculiar and unexpected ways. The main contribution of the articles in this thematic issue is to demonstrate the multiplicity of actors and structures involved in the migration process, and to recognize the important role that space plays in the life-trajectories of people on the move. Perceiving the migration process as a learning experience allows for a deeper look into the complex renegotiation of cultural and political boundaries that migrants experience in their destination countries. The development of multiple spaces and communities of belonging should be recognized as a positive outcome of the migratory process, and the narrow focus on linguistic and host country cultural identification should be avoided. Given the uncertain future of European integration, it is important to highlight the link between early experiences of international mobility and the formation of supra-national identifications. Our Southern European interviewees frequently had enriching academic experiences abroad as young adults prior to the observed migration moment in the interviews, and that made them appreciative of their European identity $-a$ trend that was less visible among the Eastern European interviewees (see Coletto \& Fullin, 2019; Fischer-Souan, 2019; Quassoli \& Dimitriadis, 2019).

Indeed, we would recommend that EU policy-makers address the issue of unequal access and/or differing levels of 'demand' for youth mobility across the EU in order to encourage the flow of information, transferability of skills and degrees, and most importantly a strong identification with Europe. This thematic issue demonstrates that deep ties have been formed between European countries that should be celebrated; yet, much more can be done to smooth the migration process on the part of governments in both the receiving and sending contexts.

\section{Acknowledgments}

We would like to thank our GEMM project colleaguesSiyka Kovacheva, Boris Popivanov, Plamen Nanov, Radka Peeva, Dorel Abraham, Octav Marcovici, Marin Burcea, Ionela Sufaru, Iraklis Dimitriadis, Giovanna Fullin, Diego Coletto, Maricia Souan-Fischer, Javier Polavieja, Alexandra Pop and Thomas Tichelbaker. The research in this thematic issue was part of the output of the EU Horizon 2020 GEMM Project (Grant agreement no. 649255).

\section{Conflict of Interests}

The authors declare no conflict of interests.

\section{References}

Arslan, A., Effenberger, A., Luecke, M., \& Omar Mahmoud, T. (2009). International labor migration and remittances beyond the crisis: Towards developmentfriendly migration policies (Kiel Policy Briefs No. 10). Kiel: Kiel Institute for the World Economy.

Barbulescu, R. (2017). From international migration to freedom of movement and back? Southern Europeans moving north in the era of retrenchment of freedom of movement rights. In J.-M. Lafleur \& M. Stanek (Eds.), South-North migration of EU citizens in times of crisis (pp. 15-32). Dordrecht: Springer.

Bauman, Z. (2000). Liquid modernity. Cambridge: Polity.

Benson, M. (2012). How culturally significant imaginings are translated into lifestyle migration. Journal of Ethnic and Migration Studies, 38(10), 1681-1696. https://doi.org/10.1080/1369183X.2012.711067

Benson, M., \& O'Reilly, K. (2016). From lifestyle migration to lifestyle in migration: Categories, concepts and ways of thinking. Migration Studies, 4(1), 20-37. 
https://doi.org/10.1093/migration/mnv015

Cameron, D. (2011, February 5). PM's speech at Munich Security Conference. Government UK. Retrieved from https://www.gov.uk/government/speeches/ pms-speech-at-munich-security-conference

Cangiano, A. (2015). Migration policies and migrant employment outcomes. Comparative Migration Studies, 2(4), 417-443.

Castoriadis, C. (1997). The imaginary institution of society. Cambridge: Polity.

Coletto, D., \& Fullin, G. (2019). Before landing: How do new European emigrants prepare their departure and imagine their destinations? Social Inclusion, 7(4), 320-329.

Conradson, D., \& Latham, A. (2005). Transnational urbanism: Attending to everyday practices and mobilities. Journal of Ethnic and Migration Studies, 31(2), 227-233. https://doi.org/10.1080/1369183 042000339891

Cummings, C., Pacitto, J., Lauro, D., \& Foresti, M. (2015). Why people move: Understanding the drivers and trends of migration to Europe. London: Overseas Development Institute.

Czaika, M., \& de Haas, H. (2014). The globalization of migration: Has the world become more migratory? International Migration Review, 48(2), 283-323.

Demireva, N. (2019). Receiving country investments and acquisitions: How migrants negotiate the adaptation to their destination. Social Inclusion, 7(4), 299-308.

Engbersen, G. (2018). Liquid migration and its consequences for local integration policies. In P. Scholten \& M. van Ostaijen (Eds.), Between mobility and migration: The multi-level governance of intra-European movement (pp. 63-76). Berlin: Springer.

Favell, A. (2008). Eurostars and Eurocities: Free movement and mobility in an integrating Europe. Oxford: Blackwell.

Fischer-Souan, M. (2019). Between 'labour migration' and 'new European mobilities': Motivations for migration of southern and eastern Europeans in the EU. Social Inclusion, 7(4), 288-298.

Florida, R. (2002). The rise of the creative class: And how it's transforming work, leisure, community and everyday life. New York, NY: Basic Books.

Gallissot, R., Rivera, A., \& Kilani, M. (1997). L'imbroglio etnico [The ethnic mess]. Bari: Dedalo.

Giulietti, C., Schluter, C., \& Wahba, J. (2013). With a lot of help from my friends: Social networks and immigrants in the UK. Population, Space and Place, 19(6), 657-670.

Glick Schiller, N. (2003). The centrality of ethnography in the study of transnational migration: Seeing the wetland instead of the swamp. In N. Foner (Ed.), American arrivals: Anthropology engages the new immigration (pp. 99-128). Santa Fe, NM: School of American Research Press.

Goulahsen, L. (2017). Understanding the complexity of identity and belonging: A case study of French fe- male migrants in Manchester and London. European Journal of Women's Studies, 24(2), 158-173. https:// doi.org/10.1177/1350506815617977

King, R. (2012). Geography and migration studies: Retrospect and prospect. Population, Space and Place, 18(2), 134-153.

Kogan, I. (2006). Labor markets and economic incorporation among recent immigrants in Europe. Social Forces, 85(2), 697-721.

Koopmans, R. (2015). Does assimilation work? Sociocultural determinants of labour market participation of European Muslims. Journal of Ethnic and Migration Studies, 42(2), 1-20.

Kovacheva, S., Popivanov, B., \& Burcea, M. (2019). (Self-)Reflecting on international recruitment: Views on the role of recruiting agencies in Bulgaria and Romania. Social Inclusion, 7(4), 330-340.

Maeva, M. (2017). Emigrant's home and preservation of cultural heritage. In N. Vukov, L. Gergova, T. Matanova, \& Y. Gergova (Eds.), Cultural heritage in migration (pp. 427-437). Sofia: Paradigma. Retrieved from http://www.migrantheritage.com/ wp-content/uploads/2018/05/sbornik-CulturalHeritage-in-Migration-2017.pdf

O’Reilly, K., \& Benson, M. (2009). Lifestyle migration: Escaping to the good life? In M. Benson \& K. O'Reilly (Eds.), Lifestyle migrations: Expectations, aspirations and experiences (pp. 1-13). Abingdon-on-Thames: Routledge.

O'Reilly, K. (2014). The role of the social imaginary in lifestyle migration: Employing the ontology of practice theory. In M. Benson \& N. Osbaldiston (Eds.), Understanding lifestyle migration: Theoretical approaches to migration and the quest for a better way of life (pp. 211-234). Basingstoke: Palgrave.

Parutis, V. (2011). "Economic migrants" or "middling transnationals"? East European migrants' experiences of work in the UK. International Migration, 52(1), 36-55. https://doi.org/10.1111/j.1468-2435. 2010.00677.x

Popivanov, B., \& Kovacheva, S. (2019). Patterns of social integration strategies: Mobilising 'strong' and 'weak' ties of the new European migrants. Social Inclusion, 7(4), 309-319.

Quassoli, F., \& Dimitriadis, I. (2019). “Here, there, in between, beyond...": Identity negotiation and sense of belonging among southern Europeans in the UK and Germany. Social Inclusion, 7(4), 341-351.

Ryan, L., \& Mulholland, J. (2014). French connections: The networking strategies of French highly skilled migrants in London. Global Networks, 14(2), 148-166.

Salazar, N. B. (2011). The power of imagination in transnational mobilities. Identities, 18(6), 576-598. https://doi.org/10.1080/1070289X.2011.672859

Triandafyllidou, A., \& Gropas, R. (2014). "Voting with their feet": Highly skilled emigrants from Southern Europe. American Behavioral Scientist, 58(12), 1614-1633. 
UK Data Service. (n.d.). The lived experiences of migration 1996-2017. UK Data Service. Retrieved from https://beta.ukdataservice.ac.uk/datacatalogue/ studies/study?id=853333

\section{About the Authors}

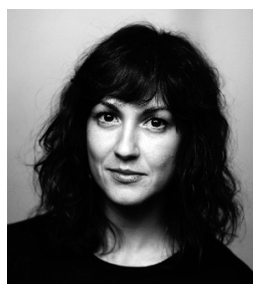

Neli Demireva (PhD) is a Senior Lecturer in Sociology at Essex University. Her research interests include migration, inter-ethnic ties, social cohesion, ethnic penalties and multiculturalism.

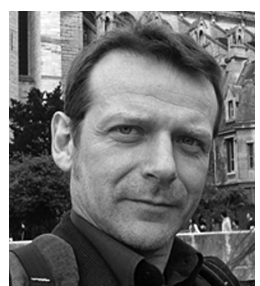

Fabio Quassoli (PhD) is an associate professor at the University of Milan-Bicocca where he teaches Qualitative Research and Intercultural Relations. In recent years, he has worked on immigration control policies, criminalisation of migrants, discrimination, multiculturalism and intercultural communication $\mathrm{He}$ is currently coordinating the Milano Bicocca team as part of a national project on media, terrorism and security. He is also participating in the WHIG project, an international research network on the governance of large metropolitan areas. 